Int. J. Dev. Biol. 55: 745-755

doi: $10.1387 / \mathrm{ijdb} .113379$ jo

\title{
Non-steroidal anti-inflammatory drugs target the pro-tumorigenic extracellular matrix of the postpartum mammary gland
}

\author{
JENEAN O'BRIEN ${ }^{1,2}{ }^{2}$, KIRK HANSEN ${ }^{3}$, DALIT BARKAN ${ }^{4}$, JEFFREY GREEN ${ }^{5}$ and PEPPER SCHEDIN ${ }^{*}, 1,2,6,7$
}

\begin{abstract}
${ }^{1}$ School of Medicine, Division of Medical Oncology, University of Colorado Anschutz Medical Campus, ${ }^{2}$ Program in Cancer Biology, University of Colorado Anschutz Medical Campus, ${ }^{3}$ School of Medicine, Department of Biochemistry and Molecular Genetics, University of Colorado Anschutz Medical Campus, ${ }^{4}$ Department of Biology, Faculty of Natural Sciences, University of Haifa, Haifa, Israel, ${ }^{5}$ Transgenic Oncogenesis and Genomics Section, Laboratory of Cell Biology and Genetics, NIH, ${ }^{6}$ University of Colorado Cancer Center and ${ }^{7}$ AMC Cancer Research Center, Denver, Colorado, USA
\end{abstract}

\begin{abstract}
Breast cancer patients diagnosed postpartum have poor prognosis. The postpartum mammary gland undergoes tissue regression to return to the pre-pregnant state. This involution is characterized by wound healing programs known to be tumor promotional in other contexts. Previous studies have shown that mammary extracellular matrix (ECM) from nulliparous rats has tumor suppressive attributes, while mammary ECM from involuting mammary glands is promotional. In models of pregnancy-associated breast cancer, non-steroidal anti-inflammatory drug (NSAID) treatment targeted to postpartum involution inhibits tumor progression, in part by suppressing COX-2 dependent collagen deposition. Because mammary ECM proteins are coordinately regulated, NSAID treatment is anticipated to result in additional protective changes in the mammary extracellular matrix. Here, systemic NSAID treatment was utilized during postpartum involution to reduce mammary COX-2 activity. ECM was isolated from actively involuting glands of rats treated with NSAIDs and compared to ECM isolated from control-involution and nulliparous rats in $3 \mathrm{D}$ cell culture and xenograft assays. Compositional changes in ECM between groups were identified by proteomics. In four distinct 3D culture assays, normal and transformed mammary epithelial cells plated in NSAID-involution ECM, phenocopied cells plated in ECM from nulliparous rats rather than ECM from control-involution rats. Tumor cells mixed with NSAID-involution ECM and injected orthotopically in mice formed smaller tumors than cells mixed with control-involution ECM. Proteomic analyses identified and 3D culture assays implicated the ECM protein tenascin-C as a potential mediator of tumor progression during involution that is decreased by NSAID treatment. In summary, NSAID treatment decreases tumor-promotional attributes of postpartum involution mammary ECM.
\end{abstract}

KEY WORDS: NSAID, breast cancer, involution, tenascin-C, proteomics, $3 D$ culture

\section{Introduction}

Full term pregnancy increases risk of breast cancer up to ten years following parturition (Schedin, 2006). Further, women with breast cancer diagnosed postpartum have poor disease outcomes compared to age-matched nulliparous women or patients pregnant at time of diagnosis and treatment (Stensheim et al., 2009). Postpartum breast cancers have been referred to as type II pregnancy-associated breast cancer (PABC) to distinguish these cancers from those diagnosed during pregnancy (Lyons et al., 2009). A physiologic window unique to type II PABC is mammary gland involution, a process that returns the lactation-competent gland to a non-secretory, quiescent state. In an effort to distinguish why type II PABC patients have worse prognoses, the normal postpartum breast microenvironment has been investigated for potential tumor-enhancing attributes. These studies reveal that postpartum involution utilizes wound healing programs for gland remodeling, including increases in matrix metalloproteinase activity,

Abbreviations used in this paper: COX-2, cyclooxygenase-2; ECM, extracellular matrix; NSAID, non-steroidal anti-inflammatory drug; PABC, pregnancy-associated breast cancer; PGEM, prostaglandin E metabolites; TN-C, tenascin-C.

\footnotetext{
*Address correspondence to: Pepper Schedin. School of Medicine, Division of Medical Oncology, University of Colorado Anschutz Medical Campus, 12801 E 17th Ave, Aurora, CO, USA.Tel: +1-303-724-3873. Fax: +1-303-724-3889. e-mail: pepper.schedin@ucdenver.edu
}

Final, author-corrected PDF published online: 28 October 2011.

ISSN: Online 1696-3547, Print 0214-6282

(C) 2011 UBC Press

Printed in Spain 
release of bioactive fragments of extracellular matrix (ECM) termed matricryptins, accumulation of fibrillar collagen, and influx of immune cells (Lund et al., 1996; Schedin et al., 2000; Schedin et al., 2004a; O'Brien et al., 2010a). The involution-hypothesis predicts these wound healing attributes drive promotion of pre-existing cancerous lesions in the postpartum gland (Bemis \& Schedin, 2000; Schedin, 2006; O'Brien \& Schedin, 2009). Preclinical data support this hypothesis, as human breast tumor cells exposed to the microenvironment of the involuting gland formed larger tumors with higher local and systemic dissemination rates than tumor cells injected into glands of nulliparous mice (Lyons et al., 2011). Further, a specific role for ECM in involution-induced tumorigenesis was elucidated in studies where breast tumor cells co-injected with ECM isolated from actively involuting glands metastasized to lung, liver and kidney at a significantly greater frequency than tumor cells mixed with mammary ECM isolated from quiescent, nulliparous rats (McDaniel et al., 2006).

Recent studies strongly implicate wound healing attributes of involution, particularly fibrillar collagen deposition, in progression of postpartum tumors. In vitro studies show that breast tumor cell interaction with fibrillar collagen leads to COX-2 (cyclooxygenase-2) upregulation, tumor cell proliferation, motility and invasion (Lyons et al., 2011). In addition, tumor cells exposed to the mammary involution microenvironment were characterized by increased intratumoral fibrillar collagen and elevated COX-2 expression, indicating fibrillar collagen of normal involution induces collagen deposition and COX-2 expression within the developing tumor (Lyons et al., 2011). Based on these observations, the wound healing microenvironment of involution represents a potential target for type II PABC prevention and treatment. Demonstrating wound healing as a therapeutic target, mice treated during postpartum involution with ibuprofen, a non-steroidal anti-inflammatory drug (NSAID) that inhibits COX-2/COX-1, displayed decreased tumor size and reduced tumor cell infiltration into the lung (Lyons et al., 2011). Demonstrating the mammary microenvironment as a target, both ibuprofen and celecoxib (a COX-2 specific inhibitor) reduced the fibrillar collagen deposition associated with normal postpartum involution (Lyons et al., 2011). NSAID-induced alterations in fibrillar collagen during involution may be accompanied by additional protective changes in mammary ECM, as mammary ECM composition is precisely regulated with the hormonal and functional state of the gland (Haslam \& Woodward, 2001; Schedin et al., 2004a). To further investigate this hypothesis, mammary matrix was isolated for use in 3D culture and tumor xenograft assays. These experiments reveal that NSAID treatment significantly reduces the pro-tumorigenic attributes of involution ECM. ECM protein composition determined by mass spectrometry identified tenascin- $C$ as an additional pro-metastatic ECM protein that is upregulated during involution and downregulated by NSAID treatment. Further functional studies show that tenascin-C contributes to the invasive phenotype of tumor cells exposed to involution matrix. These data suggest a novel ECM-based mechanism by which NSAIDs may suppress involution-induced mammary tumor progression.

\section{Results}

\section{COX-2 as a target during mammary gland involution}

COX-2 expression was assessed in the rat mammary gland to validate the use of NSAID therapy targeted to postpartum involution. Reverse-transcription PCR analysis of mammary tissue RNA isolated across stages of postpartum involution revealed that mammary COX-2 RNA levels increase during involution days 2, 4 and 6 compared to nulliparous levels (Fig. 1A). Western blot analysis confirmed that COX-2 protein levels are elevated at involution days 4-6 (Fig. 1B). Further, IHC analyses displayed almost no COX-2 protein in the nulliparous rat mammary gland, followed by elevated COX-2 expression at involution day 6 in both mammary stromal and epithelial cells (Fig. 1C). These data confirm that COX-2 is elevated in actively involuting mammary tissue both at the transcript and protein levels compared to the quiescent nulliparous gland.

Rats were treated with one of two non-specific COX inhibitor NSAIDs, aspirin or ibuprofen, by oral administration. Treatment was limited to the window of active postpartum involution, from day of weaning through Inv4-6. Doses were selected based on acceptable tolerance levels for rodents that were also within range of standard approved doses for human patients (Deng et al., 2004; Kinugasa et al., 2004; Menozzi et al., 2006; Arias \& MarquezOrozco, 2006; Lacy, 2007). To confirm that systemically delivered NSAIDs are active within the involuting mammary tissue, effector proteins downstream of COX-2 activity were measured by an ELISA specific for prostaglandin E metabolites (PGEM). Aspirin treatment resulted in a statistically significant decrease in PGEM

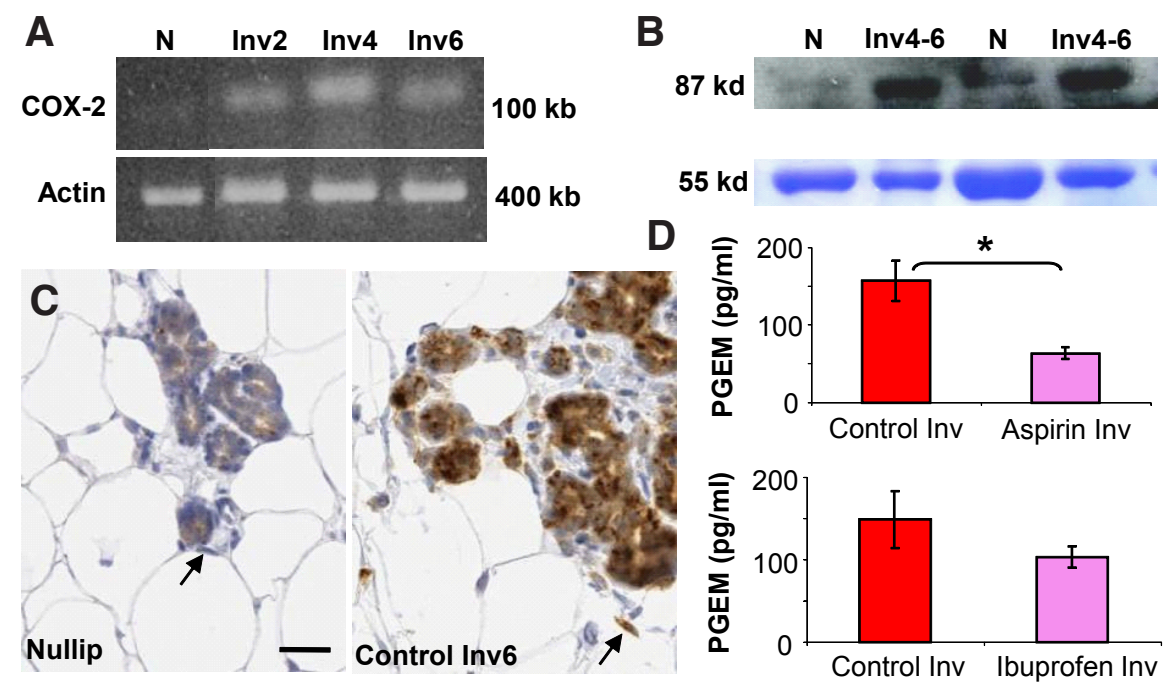

Fig. 1. COX-2 levels increase in the postpartum mammary gland and COX-2 activity can be inhibited with systemic NSAID treatment. Elevated COX-2 expression during postpartum involution as detected in rat mammary tissue by RT-PCR with actin loading control (A), Western blot with Coomassie loading control (B), and IHC analyses (C). Prostaglandin E metabolite ELISA of rat mammary tissue confirms systemic aspirin treatment decreased mammary COX-2 activity, $n=8-9$ rats/group, ${ }^{*} p=0.0085$ (D, top). Decreased COX-2 activity is also observed with ibuprofen treatment, however results did not reach statistical significance (D, bottom). N, nulliparous; Inv2, involution day 2; arrows, fibroblasts; scalebar, $40 \mu \mathrm{m}$. 
A

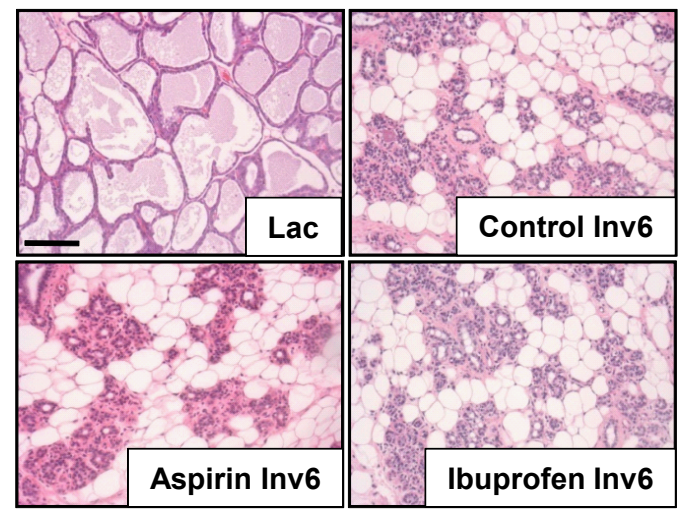

B

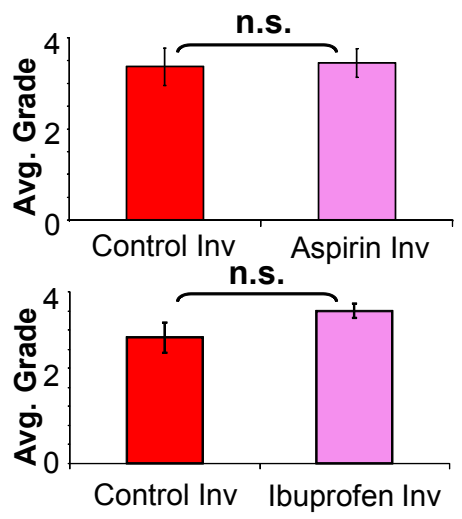

Fig. 2.Alveolar epithelial cell regression and adipocyte repopulation of mammary involution are not interrupted by NSAID treatment. H\&E stain of rat mammary tissue (A) and semi-quantitative analysis of average alveolar size/percent gland composition (B) confirms no significant histological difference in timing of epithelial cell loss or adipocyte repopulation between control and NSAID treated involution groups. Lac, lactation; Inv6, involution day 6; n.s., not significant; scalebar, $100 \mu \mathrm{m}$. concentration in Inv 4-Inv6 tissue lysates, while ibuprofen treatment gave a similar trend (Fig. 1D). Together, these data indicate that systemic NSAID treatments decrease COX-2 enzymatic activity in the target tissue, the involuting mammary gland.

\section{Mammary epithelial cell regression is not interrupted with NSAID treatment during involution}

Postpartum involution is characterized by rapid programmed mammary epithelial cell death concomitant with adipocyte repopulation, with approximately $80 \%$ of tissue remodeling complete by day 6 post-weaning (Schedin et al., 2004a). To confirm that involution progresses correctly with NSAID treatment, requisite loss of secretory epithelial cells and gland repopulation with adipocytes were evaluated from H\&E stained images. In control Inv6 glands, mammary gland regression, as measured by reduced alveolar size and adipocyte repopulation, is evident when compared to lactational mammary tissue (Fig. 2A, top). Overall, the morphology of NSAID-treated Inv6 glands was indistinguishable from control glands (Fig. 2A, bottom). A morphological grading scale was used to quantify average alveolar size, with a score of 6 representing large alveoli normally associated with full lactation and a score of 1 representing the smallest alveoli observed in a fully regressed, postpartum gland. This histological assessment revealed that there were no statistically significant differences observed in alveolar regression between control and aspirin or ibuprofen-treated involution group glands (Fig. 2B). These observations confirm that aspirin and ibuprofen inhibition of COX-2 does not interrupt epithelial cell regression and fat pad refilling necessary for weaning-induced postpartum gland remodeling.

\section{Functional in vitro analyses of ECM following NSAID treatment}

Based on previous observations that NSAIDs reduce fibrillar collagen deposition in the involuting mammary gland, it is anticipated that additional NSAID-induced changes in mammary ECM protein composition and function may occur. To globally assess ECM differences, mammary matrix was isolated at Inv4-6 from rats treated with NSAIDs from day of weaning through days 4-6 of involution (aspirin-Inv or ibuprofen-Inv), as well as from non-treated involution controls (control-Inv), and from age-matched nulliparous controls (nullip). This window of treatment was selected because it represents the window of active postpartum gland remodeling. Prior to the use of these ECM matrices in functional cell assays, it is imperative to rule out the presence of residual aspirin or ibuprofen. To this end, an in vitro COX-2 inhibitor assay that assesses COX-2 peroxidase function was performed to evaluate NSAID activity in the isolated matrices. Residual NSAIDs present in the

Fig. 3. Non-tumorigenic MCF-12A cells cultured in mammary ECM from rats treated with NSAIDs during postpartum involution phenocopy cells grown in tumor-suppressive nulliparous ECM. Brightfield images $(\mathbf{A}, \mathbf{C})$ and H\&E stained cross-sections (B,D) of non-transformed human mammary epithelial cells (MCF12A) cultured in experimental mammary ECM from nulliparous rats (N), actively involuting rats (Control Inv) or rats treated systemically with NSAIDs ibuprofen or aspirin while actively involuting (lbuprofen Inv or Aspirin Inv) in long term filter assay for 13 days (A,B) or coating assay for 72 hours (C,D). Quantification of organoid area from the coating assay $(\mathbf{E}), n=82-195$ organoids/condition, ${ }^{*} p<0.0001$. Arrows, ductal branchpoints; arrowheads, alveolar structures. Scalebars: (A) $200 \mu \mathrm{m},(B) 50$ $\mu \mathrm{m}$, (C) $400 \mu \mathrm{m}$, (D) $50 \mu \mathrm{m}$.
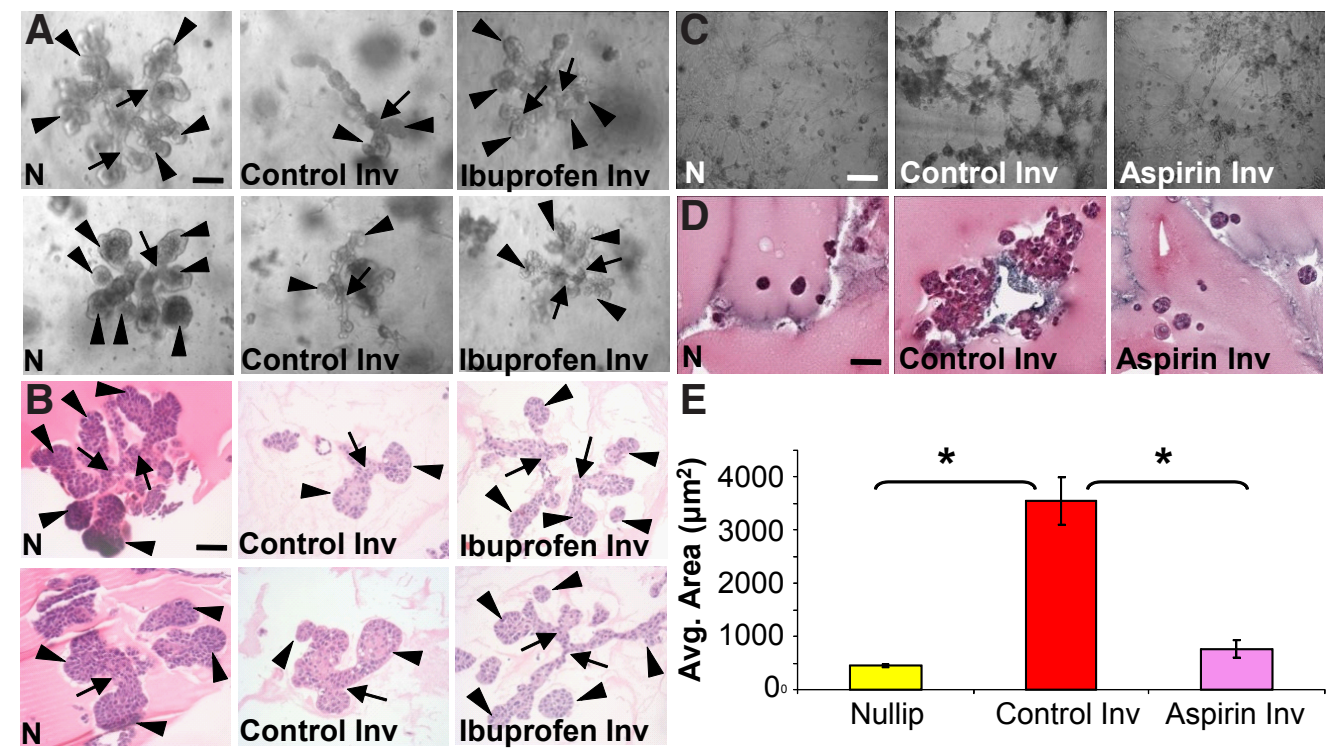
isolated mammary ECM preparations would be evident by decreased fluorescence indicating reduced COX-2 activity. Validation of the assay is demonstrated by the addition of a COX-2 inhibitor positive control (DuP-697) to recombinant COX-2 enzyme and its substrate arachidonic acid, which resulted in a $31 \%$ inhibition of COX-2 activity (decreased fluorescence) compared to a no-inhibitor control. To confirm that mammary matrix does not interfere with the fluorescent readout of this assay, control-involution ECM was added to recombinant COX-2 enzyme, its substrate and the COX-2 inhibitor DuP-697, which resulted in the same level of inhibition (33\%) observed in the absence of matrix. Finally, aspirin-involution ECM and ibuprofen-involution ECM did not inhibit COX-2 activity (-6\% and $7 \%$, respectively) and exhibited the same low level of inhibition observed in non-NSAID treated, control-involution ECM (4\%) (Table 1). These data confirm that there is no measurable NSAID activity present in mammary ECM isolated from NSAID treated rats, permitting the assessment of ECM function in 3D cell culture and xenograft assays.

To address whether systemic COX-2 inhibition reduces tumor promotional characteristics of ECM derived from actively involuting mammary glands, the response of mammary epithelial cells to experimental mammary matrices was assessed in several 3D culture assays. First, normal human mammary epithelial MCF12A cells were plated in a long term 3D filter assay designed to assess ductal branching and alveolar organization in organoids that develop in situ from single cells (Krause et al., 2008). In this assay, 12A cells plated in nulliparous ECM formed highly complex branching structures with multiple branch points (Fig. 3A, left, arrows) and alveolar clusters (Fig. 3A, left, arrowheads), reminiscent of normal in vivo epithelial organization. In contrast, control-involution ECM only permitted the organization of simpler, ductal structures (Fig. $3 \mathrm{~A}$, middle). These results support previous reports and suggest that during involution, mammary ECM does not support normal mammary epithelial cell organization (Schedin et al., 2004a). When plated in ibuprofen-involution ECM, 12A cells organized into complex branched and alveolar structures, phenocopying cells plated in nulliparous ECM rather than phenocopying cells plated in tumor-promotional control-involution ECM (Fig. 3A, right). $\mathrm{H} \& \mathrm{E}$ stained cross-sectional images of these organoids clearly display the complex morphology associated with nulliparous and

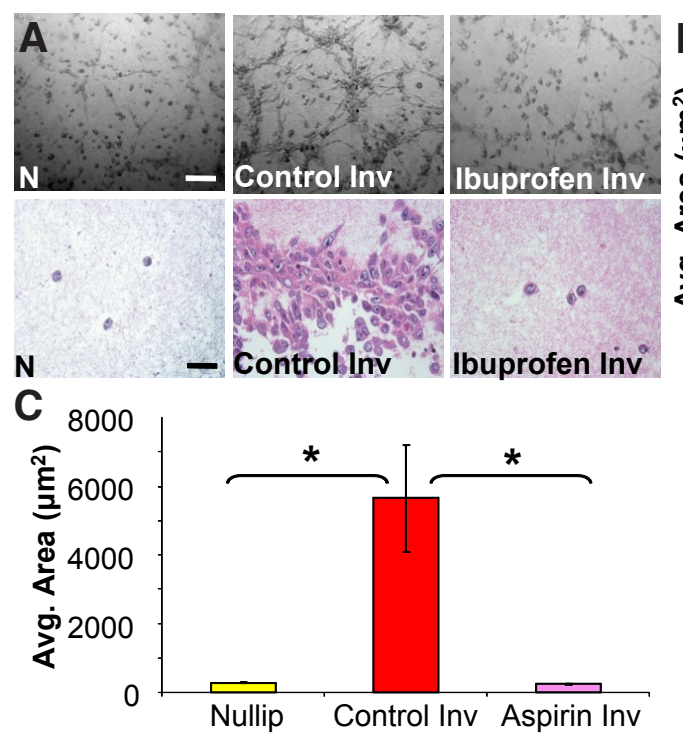

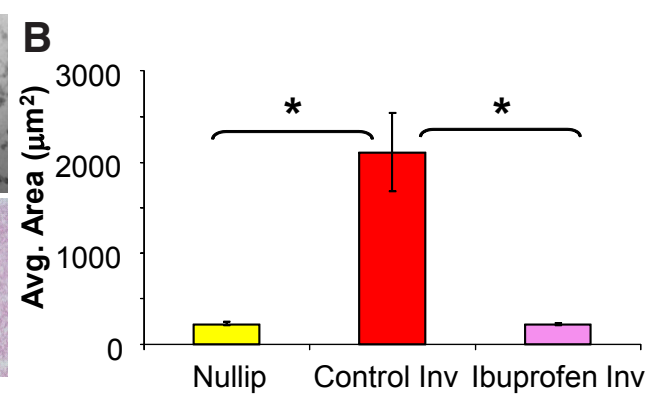

Nullip Control Inv Ibuprofen Inv
TABLE 1

\section{IN VITRO COX-2 INHIBITOR ASSAY OF RAT MAMMARY ECM}

\begin{tabular}{|c|c|c|c|}
\hline Sample & $\begin{array}{l}\% \text { coX-2 } \\
\text { Inhibition }\end{array}$ & $\begin{array}{l}\mathrm{p} \text { value, } \\
\text { compared to }\end{array}$ & Implications \\
\hline $\begin{array}{l}\text { No ECM - No Inhibitor } \\
\text { Control }\end{array}$ & 0 & & \\
\hline No ECM + DuP-697 & 31 & 0.001, No ECM & + control for COX-2 inhibition \\
\hline Control-Involution ECM & 4 & 0.246 , No ECM & ECM does not inhibit COX-2 \\
\hline $\begin{array}{l}\text { Control-Involution ECM } \\
+ \text { DuP-697 }\end{array}$ & 33 & $\begin{array}{l}\text { 0.537, No ECM } \\
\text { + DuP-697 }\end{array}$ & $\begin{array}{l}\text { ECM does not interfere } \\
\text { with fluorescent readout }\end{array}$ \\
\hline Aspirin-Involution ECM & -6 & 0.354, Control ECM & no residual aspirin in ECM \\
\hline Ibuprofen-Involution ECM & 7 & 0.740, Control ECM & no residual ibuprofen in ECM \\
\hline
\end{tabular}

ibuprofen-involution ECM in contrast to the simple structures found in the control-involution ECM group (Fig. 3B). These observations demonstrate that systemic NSAID treatment reverts the invasive organoid phenotype induced by postpartum mammary ECM to one similar to that induced by nulliparous ECM.

To observe structural organization resulting from cell motility and invasion rather than in situ development, normal and tumor cells were plated at high density using previously described short-term coating and overlay 3D assays (O'Brien et al., 2010b). In the coating assays, cells are mixed with the experimental mammary ECM before addition to a pre-set 3D Matrigel pad. In this assay, consistent with involution-ECM being tumor promotional, both normal 12A cells and Ras-transformed 12A cells (Schedin et al., 2004b) are motile and form large cellular aggregates when plated in control-involution ECM compared to cells plated in nulliparous ECM (Fig. 3 C-D and $4 \mathrm{~A}$, middle panels). Surprisingly, both normal and transformed cells plated in aspirin-involution ECM or ibuprofen-involution ECM phenocopied cells cultured in tumor-suppressive nulliparous ECM rather than cells plated in control-involution ECM (Fig. 3 C-D, $4 \mathrm{~A}$, and data not shown). Quantitative analysis of organoid size confirmed that normal and Ras-transformed $12 \mathrm{~A}$ cells plated in aspirin- and ibuprofen-involution ECM formed distinctly smaller structures than those plated in control-involution ECM (Fig. 3E, 4 B-C, and data not shown). In the overlay assays, cells are plated in complete media before addition to a pre-set 3D pad comprised of experimental mammary ECM. Similar to what was observed with the coating assays, normal $12 \mathrm{~A}$ cells plated onto aspirin-involution ECM and ibuprofen-involution ECM organized like cells plated onto tumor-suppressive nulliparous-ECM group (data not shown). These data further demonstrate that NSAIDinvolution ECM functions similar to nulliparous ECM in instructing orga-

Fig. 4. Ras-transformed MCF-12A cells cultured in mammary ECM from rats treated with NSAIDs during postpartum involution phenocopy cells grown in tumor-suppressive nulliparous ECM. Brightfield images (A top) and H\&E stained cross-sections (A bottom) of Ras-transformed human mammary epithelial cells (Ras-MCF12A) cultured in experimental mammary ECM from nulliparous rats (N), actively involuting rats (Control Inv) or rats treated systemically with NSAIDs ibuprofen or aspirin while actively involuting (Ibuprofen Inv or Aspirin Inv) in coating assay for 72 hours (A-C). Quantification of coating assay organoid area from ibuprofen (B) $n=116-207$ organoids/group, ${ }^{*} p<0.0001$, and aspirin (C) $n=50-146$ organoids/group, ${ }^{*} p \leq 0.0006$, studies. Scalebars in (A) top, $400 \mu \mathrm{m}$; bottom, $100 \mu \mathrm{m}$. 

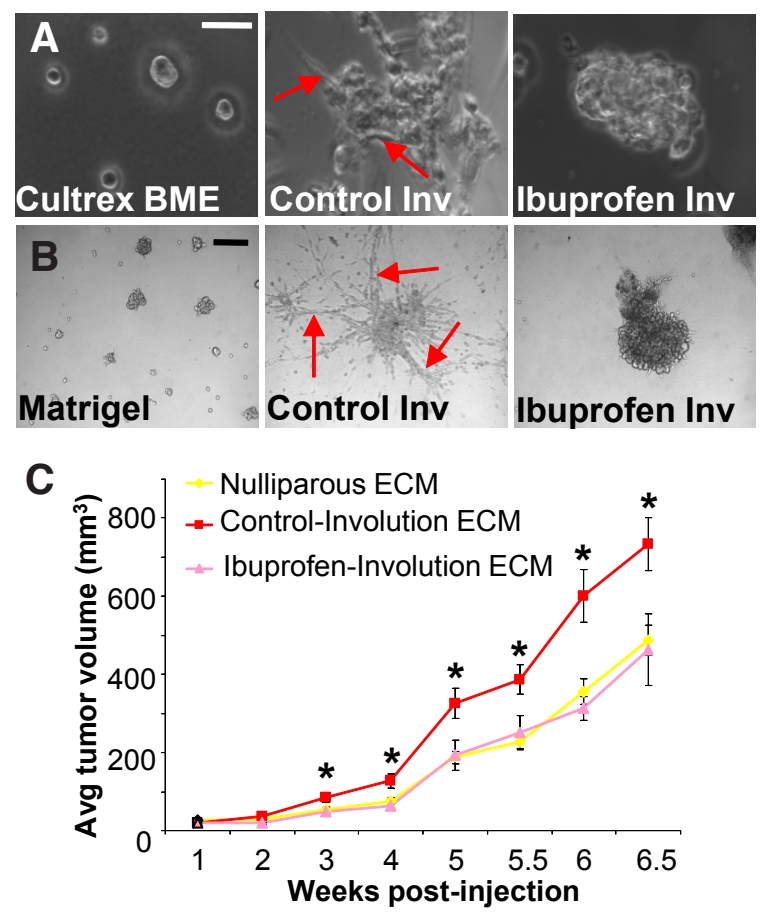

nization of both normal and transformed mammary epithelial cells.

To characterize ECM effects on an additional tumorigenic cell line, mouse mammary D2.OR cells were chosen for their ability to display a dormant phenotype. Specifically, D2.OR cells form primary mammary tumors in vivo when implanted into mammary fat pads and seed to distant sites, but remain dormant at these locations (Naumov et al., 2002; Barkan et al., 2008). To model this dormant or tumor-suppressive state, D2.0R cells can be 3D-cultured at a low density in Cultrex BME, a commercially available basement membrane substitute, similar to Matrigel (Barkan et al., 2008). As phase-contrast and brightfield images demonstrate, the D2.ORcells remain dormant in small structures, 1-4 cells, on Cultrex BME or Matrigel (Fig. 5 A-B, left panels). When these cells are exposed to
Fig. 5. Tumorigenic D2.OR cells display decreased invasion and tumor growth in presence of NSAID involution ECM. Phase contrast (A) and brightfield images (B) of tumorigenic mouse mammary D2. OR cells cultured in Cultrex BME (basement membrane extract) or Matrigel, +/-experimental mammary ECM from actively involuting rats (Control Inv) or rats treated systemically with ibuprofen while actively involuting (Ibuprofen Inv) in D2.OR dormancy assay. Average tumor volume of orthotopically injected D2.OR cells mixed with experimental ECM (C), $n=20$ tumors/group, ${ }^{*} p \leq 0.02$. Arrows, cellular extensions. Scalebars: (A) $50 \mu \mathrm{m}$, (B) $200 \mu \mathrm{m}$.

the control-involution ECM they are activated and grow into larger, invasive structures (Fig. 5 A-B, middle panels, arrows depict cellular invasion). These observations suggest that the postpartum mammary involution microenvironment has the ability to release tumor cells from a quiescent state and induce proliferation, motility and invasion. When plated in ibuprofen-involution ECM, the multicellular structures which formed display fewer invasive cellular extensions than organoids cultured in control-involution ECM, demonstrating that the mammary involution microenvironment is changed by systemic NSAID treatment in a way that decreases D2.OR cell invasion (Fig. 5 A-B, right panels). Altogether, these data demonstrate that the function of mammary ECM isolated from rats treated during postpartum involution with aspirin or ibuprofen phenocopied the function of tumor-suppressive ECM for both normal (12A) and transformed (Ras-12A and D2.OR) cells across four distinct 3D models.

\section{NSAID-induced changes in postpartum mammary ECM de- crease in vivo tumor promotion}

Next, in vivo xenograft studies were performed to assess the function of mammary ECM isolated from rats at postpartum Inv6 following systemic ibuprofen treatment initiated at time of weaning. Mammary tumorigenic D2.OR cells mixed with control-involution ECM and orthotopically injected formed larger tumors than tumor cells mixed with nulliparous ECM, consistent with involution-ECM having tumor promotional attributes (Fig. 5C, red compared to yellow). Further, tumor cells mixed with ibuprofen-involution ECM formed tumors that were significantly smaller in size than controlinvolution group tumors, but statistically indistinct from nulliparous

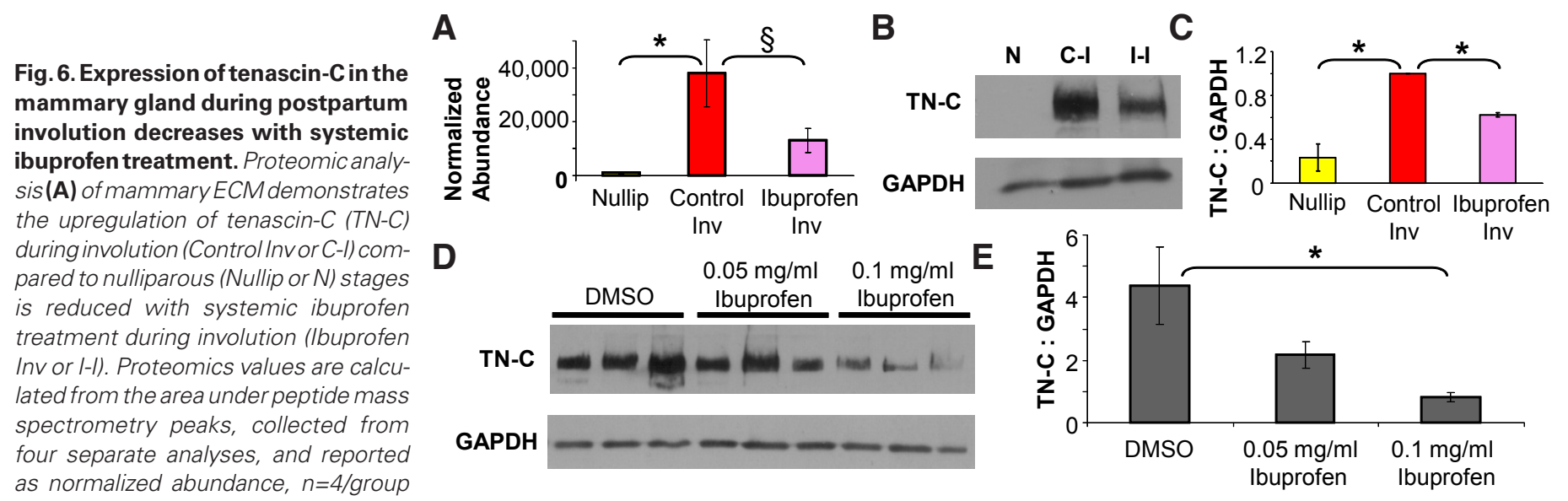

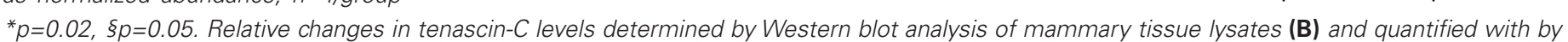

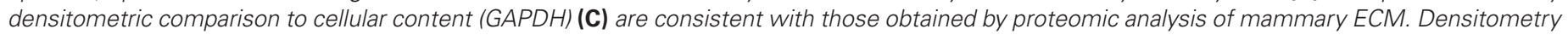

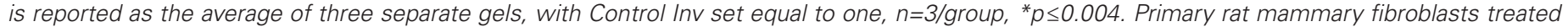

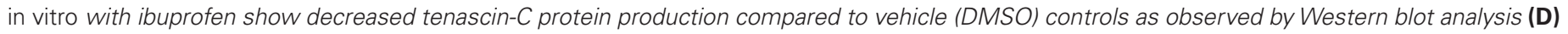
and densitometric quantification (E). Densitometry is reported as the average of each condition in triplicate, $n=3 / g r o u p,{ }^{*} p=0.047$. 


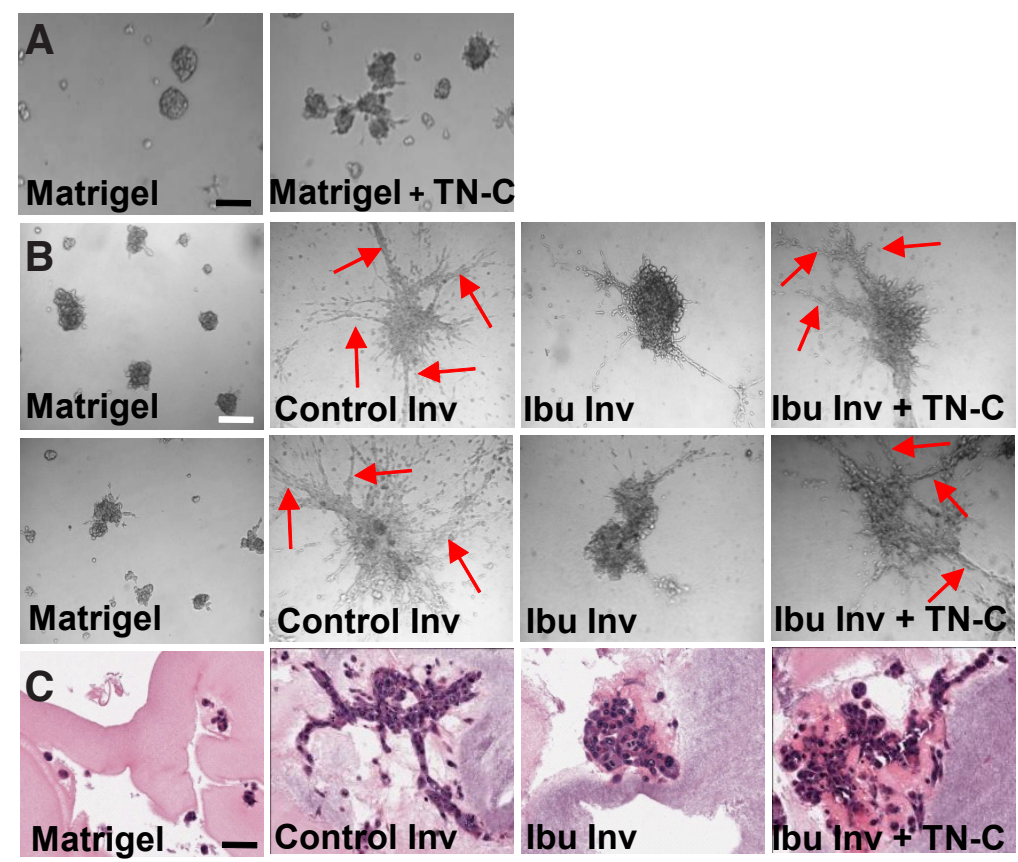

Fig. 7. Tenascin-C implicated as mediator of invasive tumor cell phenotype induced by postpartum mammary ECM. Brightfield images display addition of 5 $\mu \mathrm{g} / \mathrm{ml}$ tenascin-C (TN-C) to Matrigel promotes invasive phenotype of tumorigenic mouse mammary D2. OR cells cultured in 3D D2. OR dormancy assay (A). Further, brightfield images (B) and H\&E stained cross-sections (C) show addition of $5 \mu \mathrm{g} / \mathrm{ml}$ tenascin-C to mammary ECM from rats treated systemically with ibuprofen while actively involuting (Ibu Inv) promotes invasive phenotype in D2.OR dormancy assay.

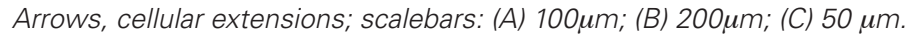

group tumors (Fig. 5C, pink). These data indicate that NSAIDinduced changes in postpartum mammary ECM decrease the ability of tumor cells to expand in an orthotopic site, and further that the ability of ibuprofen-involution ECM to suppress tumor expansion persists over the 6.5 week in vivo time course.

\section{Analysis of mammary ECM identifies tenascin-C as potential mediator of tumor promotion}

As the function of NSAID-involution matrix is more similar to tumor-suppressive nulliparous than tumor-promotional involution ECM in the assays described above, it is of interest to investigate protein differences between these matrices. Mass spectrometry analyses were performed as an unbiased approach toward identifying proteins that differ between control-involution ECM and ibuprofen-involution ECM. Proteomics techniques developed specifically for analyzing matrix samples (Hansen etal., 2009) identified numerous ECM protein differences between nulliparous and involution ECM (data not shown), however only a few matrix proteins were identified that were modulated by ibuprofen treatment. One of these, tenascin- $C$, has been previously described as pro-tumorigenic. Here tenascin$\mathrm{C}$ was identified as a candidate mediator of involutioninduced tumor progression, with elevated expression in control-involution ECM compared to nulliparous ECM, and decreased expression with postpartum ibuprofen treatment (Fig. 6A). Western blot analysis confirmed this pattern of tenascin-C expression in mammary tissue (Fig. 6B). These proteomic and Western data are consistent with previously published data showing the expression level of tenascin-C RNA and protein in nulliparous mammary tissue is very low, with a dramatic increase by Inv6, mirrored by an increase in tenascin- $C$ in mammary involution ECM (Schedin et al., 2004a). Quantitation of these data reveal an approximately $50 \%$ decrease in the level of tenascin- $C$ protein in the involuting gland with ibuprofen treatment (Fig. $6 \mathrm{~A}, \mathrm{C}$ ).

To investigate potential cellular targets of NSAIDreduced tenascin-C production, the two cell types identified by $\mathrm{IHC}$ to express COX-2 in the mammary gland (Fig. $1 \mathrm{C})$, epithelial cells and fibroblasts, were treated in vitro with increasing concentrations of ibuprofen. Low levels of tenascin-C expressed in four mammary epithelial cell lines were unchanged with ibuprofen treatment (data not shown). However, primary rat fibroblasts, the major ECM-producing cell in the mammary gland, demonstrated a dose-dependent decrease in tenascin-C protein expression with ibuprofen treatment (Fig. 6 D-E), indicating fibroblasts as a potential target for NSAID-induced ECM changes in the postpartum mammary microenvironment.

As tenascin-C is a putative tumor promoter (Jones, 2001; Orend, 2005), the effect of tenascin-C on tumor cell invasiveness was assessed in 3D culture. Addition of $5 \mu \mathrm{g} / \mathrm{ml}$ tenascin-C to dormant D2.OR cells cultured in the basement membrane extract Matrigel resulted in the appearance of small filopodia, indicative of an invasive phenotype (Fig. 7A). Tenascin-C addback to ibuprofen-involution ECM led to a partial recovery in the appearance of invasive cellular extensions observed in control-involution ECM conditions (Fig. 7 B-C). These data suggest tenascin-C upregulation in the mammary gland during postpartum involution may contribute to the tumor promotion associated with this period.

As NSAID treatment also reduced involution-induced fibrillar collagen levels, the identification of tenascin-C as another potential mediator of this promotion presents the possibility of an interactive role for these ECM proteins. Trichrome staining to distinguish

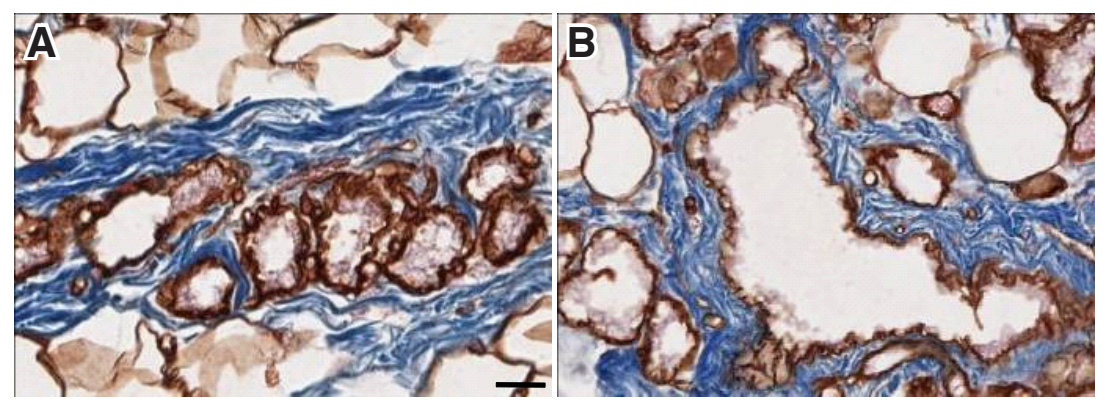

Fig. 8. Potential for interactive role of tenascin-C and fibrillar collagen in postpartum mammary involution microenvironment. Immunohistochemical stain for tenascin-C (brown) in combination with trichrome stain for fibrillar collagen (blue) display an intimate association between the two ECM proteins surrounding alveoli (A) and ducts (B) in postpartum involution mammary rat tissue. Scalebar, $20 \mu \mathrm{m}$. 
fibrillar collagen in combination with IHC staining for tenascin-C reveal an intimate association of these two matrix proteins in the mammary microenvironment of alveoli and ducts (Fig. 8). An interaction between tenascin- $\mathrm{C}$ and fibrillar collagen has previously been suggested in both human tendon and vascular smooth muscle cell reports (Riley et al., 1996; Jones et al., 1999). Further studies designed to address this potential ECM interaction in promotion of type II PABC are of high interest.

\section{Discussion}

As postpartum mammary involution shares many attributes in common with wound healing and immune-modulatory programs associated with cancer promotion, the postpartum involution microenvironment represents a window of opportunity for targeted therapies against type II PABC (Lund et al., 1996; Schedin et al., 2000; Schedin et al., 2004a; O'Brien et al., 2010a). Here we demonstrate that COX-2, an enzyme involved in initiating inflammatory responses, is upregulated in the mammary gland during involution, and represents a potential target for therapeutic intervention. Ibuprofen and aspirin are attractive intervention agents as both are affordable non-specific COX-2 inhibitors that can be used for decades with minimal side effects. In fact, COX-2 is considered a viable target for prevention and treatment in a variety of cancers (Thun et al., 1991; Elder \& Paraskeva, 1998; Kwan et al., 2007; Holmes et al., 2010).

Before exploring the use of any intervention in the postpartum period, it is important to assess drug effects on the process of mammary gland involution. Complete resolution of postpartum mammary involution is important, as incomplete or improper gland involution can contribute to tumor initiation and progression. For example, overexpression of Stat5, a signaling molecule necessary for proper mammary alveologenesis during pregnancy and lactation, results in delayed onset of involution and consequent predisposition to mammary tumor formation (lavnilovitch et al., 2002). Similarly, overexpression of transforming growth factor- $\alpha$ (TGF- $\alpha$ ) stimulates secretory epithelial cell proliferation during lactation as well as increased epithelial cell survival, which contribute to delayed involution and increased mammary tumorigenesis (Smith et al., 1995). Here, we demonstrate that COX-2 activity in the postpartum mammary gland can be decreased with systemic NSAID treatment without interruption of mammary epithelial cell regression or repopulation of the adipose tissue. Thus NSAID treatment appears to be a viable anti-inflammatory option during postpartum involution.

One mechanism by which involution promotes tumor progression is through wound-healing like changes to the mammary ECM (McDaniel et al., 2006). The dynamic interplay between the epithelial cell and its microenvironment is critical for proper function of the mammary gland (Bissell \& Aggeler, 1987). The role of the ECM in this interaction is especially important, as ECM proteins have been shown to direct both tissue-specific and stage-specific mammary epithelial cell development and to modulate breast tumor cell progression (Bemis \& Schedin, 2000; Debnath et al., 2003; Schedin et al., 2004a; Barkan et al., 2010). Many pivotal observations have been acquired through use of 3D culture techniques to study the influence of ECM on epithelial cell function. 3D assays provide a relatively easy-to-manipulate in vitro model that more accurately mimics in vivo cell-ECM interactions than $2 \mathrm{D}$ culture.
In 3D culture, mammary tumor cells can be clearly distinguished from normal epithelial cells by phenotype, whereas normal and cancer cells are typically morphologically indistinct in 2D culture (Weaver et al., 1997; Debnath et al., 2003; Shaw et al., 2004). Further, manipulation of the ECM environment can promote a normal epithelial cell to display a tumorigenic phenotype or revert mammary tumor cells to exhibit a less aggressive, smaller or hollowed normal cell organoid morphology (Weaver et al., 1997; Debnath et al., 2003; Shaw et al., 2004; Barkan et al., 2010). Therefore, 3D culture assays represent a salient tool for investigating functional cellular responses to different ECM conditions. Importantly, here we show that treatment for 4-6 days post-weaning with physiologically relevant doses of aspirin or ibuprofen was sufficient to reverse the tumor promotional aspects of mammary involution ECM, as assessed both in vitro and in vivo.

Insight into how NSAIDs reduce ECM-induced tumorigenesis can be gained through global analysis of compositional differences between ibuprofen-involution and control-involution ECM. Proteomic analysis identified tenascin-C as a potential ECM mediator of the functional differences observed in $3 \mathrm{D}$ culture and xenograft experiments, as normally high levels of tenascin-C in the postpartum mammary microenvironment are reduced with ibuprofen treatment. Tenascin-C is a hexameric glycoprotein expressed in mesenchymal tissues during development, usually lost in normal adult tissue, but re-expressed during carcinogenesis in many organs including breast, endometrium, and prostate (Vollmer, 1994). Many breast cancers upregulate tenascin-C expression, which is correlated with increased tumor grade, larger tumor size, decreased estrogenreceptor expression, and increased mortality risk (Jones, 2001; loachim et al., 2002). Postulated roles for tenascin- $C$ in a variety of cancers include increased genome instability, promotion of cell cycle progression, increased proliferation and invasion of cancer cells, and induction of increased MMP secretion from fibroblasts (Tremble et al., 1994; Orend, 2005). A variety of breast cancer cell lines exhibit increased proliferation and invasion when tenascin- $C$ isoforms are overexpressed (Hancox et al., 2009). In a previous report, the addition of tenascin- $C$ to $3 \mathrm{D}$ culture of normal mammary epithelial cells increased organoid surface roughness, elevated proliferation and promoted filling of luminal spaces (Taraseviciute et al., 2010), similar to the phenotype observed with tenascin-C addition to D2.OR cells reported here. Finally, breast cancer cellderived tenascin- $C$ has been identified as essential for metastatic outgrowth in rodent models (Oskarrson et al., 2011). This study, combined with observations reported here, that NSAIDs suppress tenascin-C, may help explain how NSAID treatment during postpartum involution reduces breast cancer metastasis to the lung (Lyons et al., 2011).

Tenascin-X, another member of the tenascin glycoprotein family, is involved in directing collagen fibril alignment, and has been previously identified as a constituent of nulliparous rat mammary ECM (Mao et al., 2002; Hansen et al., 2009). Whereas TN-C has been shown to directly signal to a variety of normal and transformed cell types to increase migration, few studies have investigated potential roles for tenascin-X in tumor progression. Transcript and protein expression studies do not display a distinct relationship, as tenascin- $X$ is upregulated in malignant mesothelioma and in the serum of breast cancer patients, but downregulated in melanoma and neurofibromatosis type-1 associated tumors (Geffrotin et al., 2000; Levy et al., 2007; Yuan et al., 2009; Zeng et al., 2011). Our 
current proteomic analyses revealed that tenascin- $\mathrm{X}$ is downregulated during postpartum involution in mammary ECM compared to nulliparous levels, and then upregulated with postpartum ibuprofen treatment (data not shown), suggesting further study of tenascin- $X$ function is of interest.

As studies continue to implicate ECM proteins in the progression of breast cancer, the need for identifying treatments that target cell-ECM interactions becomes imperative (Taraseviciute et al., 2010; Conklin et al., 2011). Previous reports investigating promotion of breast cancers that develop in the postpartum period have identified fibrillar collagen as an ECM mediator of progression that can be targeted by ibuprofen treatment (O'Brien et al., 2010a; Lyons et al., 2011). These published studies demonstrate a connection between COX-2 activity and mammary ECM composition/ function in the promotion of postpartum breast cancer. The ability to regulate ECM composition with NSAIDs may be applicable to additional tissues, as COX-2 levels were also high when collagen content increased in a wound healing skin model (Wilgus et al., 2004). However, reduced COX-2 expression correlated with elevated collagen deposition in a fibrotic lung model, implicating tissue and/or disease specificity (Bauman et al., 2010). Increasing evidence from the collagen field suggests that ECM organization and/or tension in addition to amount is important in directing tumor progression (Schedin \& Keely, 2011; Dufort et al., 2011). Both increased collagen content and increased collagen crosslinking have been shown to disrupt mammary cell organization and increase organoid size in 3D culture (Provenzano et al., 2008; Levental et al., 2009). Further, organization of collagen into radially aligned fibers, referred to as tumor-associated collagen, predicts survival in breast cancer patients (Conklin et al., 2011). Thus, it is important that future studies evaluating mammary ECM-cell interactions are designed to address effects of ECM organization as well as composition. In summary, NSAIDs present a promising intervention for type II PABC, as postpartum administration decreases tumor promotional characteristics of mammary involution ECM without interrupting postpartum remodeling.

\section{Materials and Methods}

\section{Rat breeding}

Sprague Dawley rats from Taconic Farms (Germantown, NY) were bred except the nulliparous controls. Two days after parturition, pups were normalized to $8 / \mathrm{dam}$, and weaned at 10 days of parturition to initiate involution (Inv0). NSAID treatment was initiated on the day of weaning and continued until day of sacrifice (4-6 days total). NSAIDs were delivered in powdered irradiated rodent chow 2918M (Harlan Labs, Indianapolis, IN) at $200 \mathrm{mg} /$ $\mathrm{kg}$ body weight (aspirin, Sigma, St. Louis, MO) or $30 \mathrm{mg} / \mathrm{kg}$ body weight (ibuprofen, Sigma). Rats were split into the following groups at 80 days of age: nulliparous control $(n=18)$, control Inv4 $(n=2)$, aspirin-Inv4 $(n=2)$, control-Inv5 $(n=2)$, aspirin-Inv5 $(n=3)$, control-Inv6 $(n=13)$, aspirin-Inv6 $(n=4)$, and ibuprofen-Inv6 $(n=10)$, and euthanized on designated day of involution, with the left and right mammary glands 4-6 harvested, the lymph node region removed and fixed in formalin for histology. The lymph-node free mammary tissue was snap-frozen in liquid nitrogen and stored at $-80^{\circ} \mathrm{C}$ for biochemical analysis and ECM isolation.

\section{Reverse transcription-PCR}

Rat mammary tissue was pulverized in liquid nitrogen before RNA was isolated through a QIAzol (Qiagen, Valencia, CA)-chloroform reaction using the QIAzol recommended protocol for frozen tissues and purified using an RNeasy mini kit (Qiagen). Nanodrop spectrophotometry was used to determine RNA concentration and confirm RNA quality. First strand $\mathrm{RT}$ reactions were performed by incubating $1 \mu \mathrm{g}$ RNA template with $2 \mu \mathrm{l}$ random hexamer reverse primer (Applied Biosystems, Carlsbad, CA) per reaction at $70^{\circ} \mathrm{C}$ for 10 minutes followed by addition of $25 \mathrm{mM} \mathrm{MgCl}, 1 \mathrm{X}$ reaction buffer, $2 \mu \mathrm{l}$ dNTP mix, $1 \mu \mathrm{l}$ RNase inhibitor and $1 \mu \mathrm{l}$ MuLV reverse transcriptase, all acquired from Applied Biosystems. This reaction mixture was incubated at room temperature for 15 minutes followed by heating to $37^{\circ} \mathrm{C}$ for 2 hours. Finally, the reaction mixture was heatshocked at $100^{\circ} \mathrm{C}$ for 5 minutes and cooled on ice. RNase $\mathrm{H}$ ( $0.5 \mu \mathrm{l}$, Applied Biosystems) was added to each tube, incubated at $37^{\circ} \mathrm{C}$ for 15 minutes and added to the following PCR reaction: $1 \mathrm{X}$ reaction buffer, dNTP mix, $45 \mu \mathrm{M}$ forward COX-2 or Actin primer, $50 \mu \mathrm{M}$ reverse COX-2 or Actin primer, $25 \mathrm{mM} \mathrm{MgCl}_{2}$, and $0.25 \mu \mathrm{l}$ Taq polymerase ( $5 \mathrm{units} / \mathrm{ml}$ ), and water to a final volume of 47 $\mu \mathrm{l}$ (all reagents from Applied Biosystems). Forty cycles of 5 minutes at 95 ${ }^{\circ} \mathrm{C}, 40$ seconds at $94^{\circ} \mathrm{C}, 40$ seconds at $60^{\circ} \mathrm{C}, 40$ seconds at $72^{\circ} \mathrm{C}$ and a final 10 minutes at $72^{\circ} \mathrm{C}$ were performed on an Eppendorf Mastercylcer. Four $\mu$ l of each product was run on a $1.8 \%$ agarose gel for imaging.

\section{Western blot analyses}

Equal weights of pulverized frozen mammary tissue samples were pooled by groups with 5-6 rats per group or primary fibroblasts from one $10 \mathrm{~cm}^{2}$ plate were homogenized in lysis buffer (10 mM Tris, $\mathrm{pH} 7.4,150$ $\mathrm{mM} \mathrm{NaCl}, 0.1 \%$ SDS, $1 \%$ Sodium Deoxycholate, 1\% Triton X-100, 200 $\mu \mathrm{g} / \mathrm{ml}$ PMSF, 1 X PI Cocktail, Sigma). Equal protein was loaded at 10-20 $\mu \mathrm{g} / \mathrm{well}$. Protein separation was achieved by SDS-PAGE using a $7.5 \% \mathrm{gel}$ at 60 volts for 30 minutes followed by 120 volts for 90 minutes, followed by transferring to nitrocellulose membrane (Amersham Biosciences, Pittsburgh, PA) overnight at 22 volts at $4^{\circ} \mathrm{C}$. After blocking the membrane for 1 hour at room temperature in $10 \%$ milk, membranes were incubated in antibodies to COX-2 (1:2000, Caymen Chemical, Ann Arbor, MI, 1 hour at room temperature), tenascin-C (1:100, Chemicon, Billerica, MA, overnight at $\left.4^{\circ} \mathrm{C}\right)$, and GAPDH (1:1000, Sigma, 1 hour room temperature) diluted in wash buffer (10 mM Tris- $\mathrm{HCl}, \mathrm{pH} 8.0,150 \mathrm{mM} \mathrm{NaCl}, 0.1 \%$ Tween-20). Three 10 minute washes were followed by anti-rabbit Hrp conjugate secondary antibody (1:1000, R\&D Systems) incubated at room temperature for one hour. After three additional 10 minute washes, the membrane was incubated in Pierce ECL Western Blotting Substrate (ThermoScientific, Waltham, MA) for 2 minutes before exposure to film.

\section{Prostaglandin E metabolite ELISA}

Eighty $\mathrm{mg}$ frozen mammary tissue was added to $400 \mu$ l lysis buffer $(0.1 \mathrm{M}$ phosphate buffer, pH 7.4, 1 mM EDTA, $10 \mu \mathrm{M}$ indomethacin (Sigma), 1X PI cocktail (Sigma) and homogenized. Samples were then centrifuged at $14,000 \mathrm{x} \mathrm{g}$ for 10 minutes at $4^{\circ} \mathrm{C}$. $250 \mu \mathrm{l}$ of each supernatant was used in the Prostaglandin E Metabolite EIA kit (Caymen Chemical) starting at the derivatization step. Briefly, 13,14-dihydro-15-keto PGA ${ }_{2}$ and 13,14-dihydro15-keto $P G E_{2}$ are converted to a single, stable derivative detected by ELISA. Data was collected on a VERSAmax Microplate Reader (Molecular Devices, Sunnyvale, CA) using SoftmaxPro software. Samples were run in triplicate.

\section{Immunohistochemistry, imaging and quantification}

Mammary tissue and organoids were cut into 4- $\mu \mathrm{m}$ sections and pretreated with Dako Target Retrieval Solution at $125^{\circ} \mathrm{C}$ under pressure for 5 min. Primary antibodies were applied at the following dilutions for $60 \mathrm{~min}$ at room temperature: COX-2 1:400 (Cayman Chemical), tenascin-C 1:100 (Chemicon). Immunoreactivity was detected using Dako Envision+ Mouse. 3,3-diaminobenzidine was used as the chromagen in all tissues. H\&E stain of organoids was performed according to published methods (Lopez-De Leon \& Rojkind, 1985). H\&E stained 10X organoid images (4 images per well, 3 wells/group) were analyzed using Image $J$ to quantify total organoid area by converting images to grayscale, adjusting the threshold intensity, and analyzing particles using the following parameters: size: $0.00001-1$ $\mathrm{cm}^{2}$, circularity $0-1$, show: 'outlines,' display results, summarize, exclude on edges, include holes. Trichrome stain was performed as previously described (O'Brien et al., 2010a). 


\section{Semi-quantitative histological analysis}

For each mammary gland, a representative image of each of the following categories was taken: small (S), average (A) or large (L) size alveoli. The percentage of the gland represented by each image was noted. The images were assigned a rank value based on the size of the alveoli from 1 for small (later involution) and 6 for large (early involution). The image and percentage assessment was performed by two investigators blinded to the animal groups. Histological scores were calculated with the following equation: $\left(S\right.$ rank $^{*} S$ percentage $)+\left(A\right.$ rank $^{*} A$ percentage $)$ $+\left(\mathrm{L}\right.$ rank $^{*} \mathrm{~L}$ percentage), again with a larger number representing a less regressed or early involution alveolar size. Scores were averaged within groups, $\mathrm{n}=8-9$ rats/group

\section{Mammary extracellular matrix isolation}

Matrix isolation was performed as previously described (O'Brien et al., $2010 b)$. Briefly, frozen \#4-6 LN free rat mammary glands were pulverized and homogenized at $4{ }^{\circ} \mathrm{C}$ in a high salt/N-ethylmaleimide (NEM) solution (3.4 M NaCl, 50 mM Tris-HCl pH 7.4, 4 mM EDTA, 2 mM NEM (Sigma)) containing $2 X$ proteinase inhibitor (PI) cocktail (Sigma) and PMSF (200 $\mu \mathrm{g} /$ $\mathrm{ml}$, Sigma). Lysates were enriched for ECM by 2 cycles of centrifugation $\left(\mathrm{RCF}_{\max } 110,000 \times \mathrm{g}, 30 \mathrm{~min}, 4^{\circ} \mathrm{C}\right)$, with pellets resuspended in high salt/ NEM buffer. ECM enriched pellets were then resuspended in mid-salt/urea solution (2 M urea, $0.2 \mathrm{M} \mathrm{NaCl}, 50 \mathrm{mM}$ Tris- $\mathrm{HCl} \mathrm{pH} \mathrm{7.4,} 4 \mathrm{mM}$ EDTA, $2 \mathrm{mM}$ NEM with 2X PI cocktail and PMSF $(100 \mu \mathrm{g} / \mathrm{ml}))$ and agitated overnight at $4^{\circ} \mathrm{C}$. Samples were centrifuged at $110,000 \times \mathrm{g}$, and the ECM-enriched supernatants dialyzed for 48 hours (molecular weight cutoff 12-14 kDa, Spectrum) against low salt buffer with one buffer change after 24 hours $(0.15 \mathrm{M} \mathrm{NaCl}, 50 \mathrm{mM}$ Tris- $\mathrm{HCl} \mathrm{pH} \mathrm{7.4,} 2 \mathrm{mM}$ EDTA with 2mM NEM in the first 24 hours replaced by $30 \mu \mathrm{g} / \mathrm{mL}$ Gentamicin (Sigma) in the second 24 hours), and then against sera-free media for 24 hours (DMEM/F12 media with $15 \mathrm{mM}$ HEPES and L-glutamine (Hyclone), supplemented $10 \mu \mathrm{g} / \mathrm{mL}$ insulin (Gibco) and $20 \mathrm{ng} / \mathrm{ml} \mathrm{EGF} \mathrm{(BD} \mathrm{Biosciences)} \mathrm{and} 1 \mu \mathrm{g} /$ $\mathrm{mL}$ Gentamicin) at $4^{\circ} \mathrm{C}$. Matrices were used within 2 weeks of isolation and stored on ice at $4^{\circ} \mathrm{C}$. ECM protein integrity was stable under these storage conditions (data not shown). For each ECM preparation, mammary glands were pooled from 5-6 rats per group, therefore one controlinvolution group is Inv4-6 and the aspirin-involution group is Inv4-6. High molecular weight ECM proteins LN, FN and Collagen I were enriched for while low molecular weight cellular contaminant GAPDH was decreased, as previously published (O'Brien et al., 2010b).

\section{cOX-2 inhibitor assay}

The assay was performed according to COX fluorescent inhibitor screening assay kit (Cayman Chemical) instructions specifically using $10 \mu \mathrm{l}$ of each mammary ECM prep in triplicate, $10 \mu \mathrm{l}$ human recombinant COX-2 enzyme, and $10 \mu \mathrm{l}$ COX-2 inhibitor DuP-697. Data was collected on a Synergy 2 fluorescent plate reader (Biotek, Winooski, VT) using Gen5 software. COX-2 first catalyzes the conversion of its substrate arachidonic acid to a hydroperoxy endoperoxide (PGG2), and then the peroxidase function of COX-2 reduces PGG2 to the alcohol PGH2 (Rao \& Knaus, 2008). The COX-2 inhibitor assay utilized requires combining the enzyme COX-2 and its substrate arachidonic acid with 10-acetyl-3,7dihydroxyphenoxazine (ADHP). COX-2 activity is then measured by the fluorescence created when hydrogen peroxide, produced by reduction of PGG2, reacts with the ADHP to produce the highly fluorescent compound resorufin.

\section{Cell culture}

Normal, immortalized human mammary epithelial MCF12A, Rastransformed MCF12A, and tumorigenic mouse mammary D2.OR cells were used for 3D culture studies. 12A and Ras12A cells were cultured in DMEM/F12 Medium with $15 \mathrm{mM}$ Hepes and L-glutamine (Hyclone, Waltham, MA), 5\% horse serum (Hyclone), $10 \mathrm{ug} / \mathrm{ml}$ insulin (Gibco, Carlsbad, CA), 500 ng/ml hydrocortisone (Sigma), 20 ng/ml RHu EGF (BD
Biosciences, Franklin Lakes, NJ), and $100 \mathrm{ng} / \mathrm{ml}$ cholera toxin (List Labs, Campbell, CA) with $100 \mu \mathrm{g} / \mathrm{mL}$ G418 (Hyclone) added to the Ras-12A media. D2.OR cells were cultured in DMEM high glucose media with $10 \%$ fetal bovine serum (Hyclone), $100 \mu \mathrm{g} / \mathrm{mL}$ penicillin (Gibco) and 100 units/ $\mathrm{mL}$ streptomycin (Gibco). All assays were performed in triplicate under sterile conditions with 3-6 experimental replicates. Coating and overlay assays were performed as previously described (O'Brien et al., 2010b). Briefly, coating assays in 96 well plates: $100 \mu \mathrm{l} /$ well pads are $5 \%$ horse serum and Matrigel (BD Biosciences) diluted 1:1 with sera-free media and incubated for 24 hours. Cells are harvested, counted, rinsed 1x in PBS and resuspended in $200 \mu \mathrm{l} / \mathrm{well}$ of $200 \mu \mathrm{g} / \mathrm{ml}$ Matrigel or experimental ECM (diluted in sera-free media) at 22,500 12A cells/well or 15,000 Ras$12 A$ cells/well. Length of assay is $24-96$ hours. Overlay assays in 96 well plates: $100 \mu \mathrm{l} /$ well pads are $5 \%$ horse serum and $200 \mu \mathrm{g} / \mathrm{ml}$ Matrigel or experimental ECM (diluted in sera-free media defined above) diluted 1:1 with sera-free media and incubated for 24 hours. Cells are harvested, counted, rinsed $1 \mathrm{x}$ in PBS and resuspended in $200 \mu \mathrm{l} /$ well of complete media at 45,000 12A cells/well or 30,000 Ras-12A cells/well. Length of assay is 24-96 hours. Long term filter assays in $0.4 \mu \mathrm{m}$ pore transwell inserts in 12 well plates, modified from (Krause et al., 2008): Cells are harvested, counted, rinsed $1 \mathrm{x}$ in PBS and resuspended in $0.5 \mathrm{ml} /$ well of $600 \mu \mathrm{g} / \mathrm{ml}$ Matrigel or experimental ECM (diluted in sera-free media) diluted 1:1 with Matrigel at 40,000 12A cells/well. After incubating for 1 hour, 2 $\mathrm{ml}$ complete media are added to each well and $600 \mu \mathrm{l}$ complete media onto transwell insert. Length of assay is 10-14 days. D2.OR dormancy assays in 8 well chamber slides adapted from (Barkan et al., 2008): Pads are $100 \%$ Matrigel, produced by spreading $40 \mu \mathrm{l}$ from the center of each well and incubating for 20 minutes. Slides are then placed on ice, and 40 $\mu l$ Matrigel is used to fill in the edges before pads are incubated for 24 hours. Cells are harvested, counted, rinsed $1 \mathrm{x}$ in PBS and resuspended in $200 \mu \mathrm{l} /$ well of $200 \mu \mathrm{g} / \mathrm{ml}$ Matrigel or experimental ECM (diluted in sera-free media) at 5,000 D2.OR cells/well. Purified human tenascin-C (>97\% pure, Millipore, Billerica, MA) was added at $5 \mu \mathrm{g} / \mathrm{ml}$ to $200 \mu \mathrm{g} / \mathrm{ml}$ Matrigel or ibuprofen-involution ECM in addback experiments. Length of assay is 2-3 days. Cells from overlay, coating and D2.OR dormancy assays were fixed in methacarn (60\% methanol, $30 \%$ choloroform, $10 \%$ acetic acid) for 5 minutes. Long term filter assays were fixed in 10\% NBF for 24 hours. Fixed organoids were embedded in paraffin for histological sectioning. Primary rat fibroblasts were isolated as previously described (Hattar et al., 2009), cultured in DMEM/F12 with $15 \mathrm{mM}$ hepes and 20\% fetal bovine serum (Hyclone) with $0.1 \%$ DMSO, $0.05 \mathrm{mg} / \mathrm{ml}$ ibuprofen, or $0.1 \mathrm{mg} / \mathrm{ml}$ ibuprofen added at time of plating, incubated for 72 hours and harvested for Western blot analyses.

\section{Mouse xenograft model}

$1 \times 10^{6} \mathrm{D} 2$.OR cells labeled with green fluorescent protein (GFP) were mixed with $20 \mu$ l undiluted mammary experimental ECM and injected in the fat pads of left and right mammary gland 4 of 6 -week old nulliparous SCID mice fromTaconic (10 mice per group). Tumors were measured 1-2 times/week until time of sacrifice at 6.5 weeks post-tumor cell injection.

\section{Proteomic analyses}

Rat mammary ECM samples were analyzed by 1D-PAGE, followed by manual gel band excision and in-gel trypsin digestion. Trypsin digests were analyzed using a GeLC-MS/MS approach on a LIT-ICR (LTQ-FT Ultra) mass spectrometer. The peak area intensities of ion peptides were aligned and quantitated using Progenesis LC-MS 3.0 software (NonLinear Dynamics, Newcastle, UK) with peptide identification performed using MASCOT (Matrix Science, London, UK). In-house Excel scripts were used to combine peptide data from 4 independent experiments. For each ECM protein, abundance was calculated as total peak area intensity of all unique peptides, then normalized to nulliparous ECM intensity. Western blot validation was used to check quantification accuracy for tenascin-C and select ECM proteins. 


\section{Statistical analyses}

Unpaired t test analyses were performed using GraphPad InStat software.

\section{Acknowledgements}

The authors would like to acknowledge the assistance of Shauntae McDaniel and Raphael Nemenoff with COX-2 PCR and westerns, K. Patricia Bell with IHC, Karla Hedman with animal husbandry, Lauren Kiemele with proteomic analysis and Alice Castile and Jaime Fornetti with ECM isolation and $3 D$ culture.

Supported by DOD Synergistic Idea Award \#BC060531, Komen Foundation \#KG090629, and Mary Kay Ash Foundation \#078-08 to PS, NIH NCRR \#S10RR023015 and R21 \#CA132741 to KH and DOD Predoctoral Grant \#BC073482 to JO. This work was supported in part by the Intramural Program of the Center for Cancer Research, National Cancer Institute, NIH.

\section{References}

ARIAS OR, MARQUEZ-OROZCO MC (2006) Aspirin, acetaminophen, and ibuprofen: their effects on orthodontic tooth movement. Am J Orthod Dentofacial Orthop 130: 364-370.

BARKAN D, KLEINMAN H, SIMMONS JL, ASMUSSEN H, KAMARAJU AK, HOENORHOFF MJ, LIU ZY, COSTES SV, CHO EH, LOCKETT S, KHANNA C, CHAMBERS AF, GREEN JE (2008) Inhibition of metastatic outgrowth from single dormant tumor cells by targeting the cytoskeleton. Cancer Res. 68: 6241-6250.

BARKAN D, EL TOUNY LH, MICHALOWSKI AM, SMITH JA, CHU I, DAVIS AS, WEBSTER JD, HOOVER S, SIMPSON RM, GAULDIE J, GREEN JE (2010) Metastatic growth from dormant cells induced by a col-I-enriched fibrotic environment. Cancer Res. 70: 5706-5716.

BAUMAN KA, WETTLAUFER SH, OKUNISHI K, VANNELLA KM, STOOLMAN JS, HUANG SK, COUREY AJ, WHITE ES, HOGABOAM CM, SIMON RH, TOEWS GB, SISSON TH, MOORE BB, PETERS-GOLDEN M. (2010). The antifibrotic effects of plasminogen activation occur via prostaglandin E2 synthesis in humans and mice. J Clin Inv 120: 1950-1960.

BEMIS LT, SCHEDIN P (2000) Reproductive state of rat mammary gland stroma modulates human breast cancer cell migration and invasion. Cancer Res. 60: 3414-3418.

BISSELL MJ, AGGELER J (1987) Dynamic reciprocity: how do extracellular matrix and hormones direct gene expression? Prog Clin Biol Res 249: 251-262.

CONKLINMW, EICKHOFFJC, RICHING KM, PEHLKECA, ELICEIRIKW, PROVENZANO PP, FRIEDL A, KEELY PJ (2011) Aligned collagen is a prognostic signature for survival in human breast carcinoma. Am. J. Pathology 178: 1221-1232.

DEBNATH J, MUTHUSWAMY SK, BRUGGE JS (2003) Morphogenesis and oncogenesis of MCF-10A mammary epithelial acini grown in three-dimensional basement membrane cultures. Methods 30: 256-268.

DENG S, DENG PY, JIANG JL, YE F, YU J, YANG TL, DENG HD, LI YJ (2004) Aspirin protected against endothelial damage induced by LDL: role of endogenous NO synthase inhibitors in rats. Acta Pharmacol. Sinica 25: 1633-1639.

DUFORT CC, PASZEK MJ, WEAVER VM (2011) Balancing forces: architectural control of mechanotransduction. Nat Rev Mol Cell Biol 12: 308-319.

ELDER DJ, PARASKEVA C (1998) COX-2 inhibitors for colorectal cancer. Nat Med 4: 392-393.

GEFFROTIN C, HORAK V, CRECHET F, TRICAUD Y, LETHIAS C, VINCENTNAULLEAU S, VIELH P (2000) Opposite regulation of tenascin-C and tenascin-X in MeLiM swine heritable cutaneous malignant melanoma. Biochim Biophys Acta 1524: 196-202.

HANCOX RA, ALLEN MD, HOLLIDAY DL, EDWARDS DR, PENNINGTON CJ, GUTTERY DS, SHAW JA, WALKER RA, PRINGLE JH, JONES JL (2009) Tumourassociated tenascin-C isoforms promote breast cancer cell invasion and growth by matrix metalloproteinase-dependent and independent mechanisms. Breast Cancer Res 11: R24.

HANSEN KC, KIEMELE L, MALLER O, O'BRIEN J, SHANKAR A, FORNETTI J, SCHEDIN P (2009) An in-solution ultrasonication-assisted digestion method for improved extracellular matrix proteome coverage. Mol Cell Proteomics 8: 1648-1657.

HASLAM SZ, WOODWARD TL (2001) Reciprocal regulation of extracellular matrix proteins and ovarian steroid activity in the mammary gland. Breast Cancer Res
3: 365-372.

HATTAR R, MALLER O, MCDANIEL S, HANSEN KC, HEDMAN KJ, LYONS TR, LUCIA S, WILSON RS, JR., SCHEDIN P (2009) Tamoxifen induces pleiotrophic changes in mammary stroma resulting in extracellular matrix that suppresses transformed phenotypes. Breast Cancer Res 11: R5.

HOLMES MD, CHEN WY, LI L, HERTZMARK E, SPIEGELMAN D, HANKINSON SE (2010) Aspirin intake and survival after breast cancer. J Clin Oncol28: 1467-1472.

IAVNILOVITCH E, GRONER B, BARASH I (2002) Overexpression and forced activation of stat 5 in mammary gland of transgenic mice promotes cellular proliferation, enhances differentiation, and delays postlactational apoptosis. Mol Cancer Res 1: 32-47.

IOACHIM E, CHARCHANTIA, BRIASOULIS E, KARAVASILIS V, TSANOU H, ARVANITIS DL, AGNANTIS NJ, PAVLIDIS N (2002) Immunohistochemical expression of extracellular matrix components tenascin, fibronectin, collagen type IV and laminin in breast cancer: their prognostic value and role in tumour invasion and progression. Eur J Cancer 38: 2362-2370.

JONES PL, JONES FS, ZHOU B, RABINOVITCH M (1999) Induction of vascular smooth muscle cell tenascin- $C$ gene expression by denatured type I collagen is dependent upon a beta3 integrin-mediated mitogen-activated protein kinase pathway and a 122-base pair promoter element. J Cell Sci 112 (Pt 4): 435-445.

JONES PL (2001) Extracellular matrix and tenascin-C in pathogenesis of breast cancer. Lancet 357: 1992-1994.

KINUGASAS, SMITHE, DREW PA, WATSON DI, JAMIESON GG (2004) Aspirin and indomethacin for the prevention of experimental port-site metastases. Surgical Endoscopy 18: 834-838.

KRAUSE S, MAFFINI MV, SOTO AM, SONNENSCHEIN C (2008) A novel 3D in vitro culture model to study stromal-epithelial interactions in the mammary gland. Tissue Engineering 14: 261-271.

KWAN ML, HABEL LA, SLATTERY ML, CAAN B (2007) NSAIDs and breast cancer recurrence in a prospective cohort study. Cancer Causes Control 18: 613-620.

LACY CF, ARMSTRONG, LORA L., GOLDMAN, MORTON P., AND LANCE, LEONARD L. (2007) Drug Information Handbook: A Comprehensive Resource for All Clinicians and Healthcare Professionals, 15 edn. Hudson, $\mathrm{OH}$ : Lexi-Comp..

LEVENTAL KR, YU H, KASS L, LAKINS JN, EGEBLAD M, ERLER JT, FONG SF, CSISZAR K, GIACCIAA, WENINGER W, YAMAUCHI M, GASSER DL, WEAVER VM (2009) Matrix crosslinking forces tumor progression by enhancing integrin signaling. Cell 139: 891-906.

LEVYP, RIPOCHE H, LAURENDEAU I, LAZAR V, ORTONNE N, PARFAITB, LEROY $K$, WECHSLER J, SALMON I, WOLKENSTEINP, DESSEN P, VIDAUD M, VIDAUD D, BIECHE I (2007) Microarray-based identification of tenascin C and tenascin $\mathrm{XB}$, genes possibly involved in tumorigenesis associated with neurofibromatosis type 1. Clin Cancer Res 13: 398-407.

LOPEZ-DE LEON A, ROJKIND M (1985) A simple micromethod for collagen and total protein determination in formalin-fixed paraffin-embedded sections. $J$ Histochem Cytochem 33: 737-743.

LUND LR, ROMER J, THOMASSET N, SOLBERG H, PYKE C, BISSELL MJ, DANO K, WERB Z (1996) Two distinct phases of apoptosis in mammary gland involution: proteinase-independent and -dependent pathways. Development (Cambridge, England) 122: 181-193.

LYONS TR, SCHEDIN PJ, BORGES VF (2009) Pregnancy and breast cancer: when they collide. J. Mammary Gland Biol. Neoplasia 14: 87-98.

LYONS TR, O'BRIEN J, BORGES V, CONKLIN MW, KEELY PJ, ELICEIRI KW, MARUSYK A, TAN AC, SCHEDIN P (2011) Postpartum mammary gland involution drives progression of ductal carcinoma in situ through collagen and COX-2. Nature Med 17:1109-1115.

MAO JR, TAYLOR G, DEAN WB, WAGNER DR, AFZAL V, LOTZ JC, RUBIN EM, BRISTOW J (2002) Tenascin-X deficiency mimics Ehlers-Danlos syndrome in mice through alteration of collagen deposition. Nat Genet 30: 421-425.

MCDANIELSM, RUMERKK, BIROC SL, METZRP, SINGHM, PORTERW, SCHEDIN $P(2006)$ Remodeling of the mammary microenvironment after lactation promotes breast tumor cell metastasis. Am. J. Pathology 168: 608-620.

MENOZZI A, POZZOLI C, GIOVANNINI E, SOLENGHI E, GRANDI D, BONARDI S, BERTINI S, VASINA V, CORUZZI G (2006) Intestinal effects of nonselective and selective cyclooxygenase inhibitors in the rat. Eur. J. Pharmacol. 552: 143-150.

NAUMOV GN, MACDONALD IC, WEINMEISTER PM, KERKVLIET N, NADKARNI KV, WILSON SM, MORRIS VL, GROOM AC, CHAMBERS AF (2002) Persistence 
of solitary mammary carcinoma cells in a secondary site: a possible contributor to dormancy. Cancer Res. 62: 2162-2168.

O'BRIEN J, SCHEDIN P (2009) Macrophages in breast cancer: do involution macrophages account for the poor prognosis of pregnancy-associated breast cancer? J. Mammary Gland Biol. Neoplasia 14: 145-157.

O'BRIEN J, LYONS T, MONKS J, LUCIA MS, WILSON RS, HINES L, MAN YG, BORGES V, SCHEDIN P (2010a) Alternatively activated macrophages and collagen remodeling characterize the postpartum involuting mammary gland across species. Am. J. Pathology 176: 1241-1255.

O'BRIEN J, FORNETTI J, SCHEDIN P (2010b) Isolation of mammary-specific extracellular matrix to assess acute cell-ECM interactions in 3D culture. J. Mammary Gland Biol. Neoplasia 15: 353-364.

OREND G (2005) Potential oncogenic action of tenascin-C in tumorigenesis. Int. J. Biochem. Cell Biol. 37: 1066-1083.

OSKARRSON T, ACHARYYA S, ZHANG XH, VANHARANTA S, TAVAZOIE SF, MORRIS PG, DOWNEY RJ, MANOVA-TODOROVAK, BROQI E, MASSAGUE J (2011) Breast cancer cells produce tenascin $C$ as a metastatic niche component to colonize the lungs. Nature Med 17: 867-874.

PROVENZANO PP, INMAN DR, ELICEIRI KW, KNITTEL JG, YAN L, RUEDEN CT, WHITE JG, KEELY PJ (2008) Collagen density promotes mammary tumor initiation and progression. BMC medicine 6: 11.

RILEY GP, HARRALL RL, CAWSTON TE, HAZLEMAN BL, MACKIE EJ (1996) Tenascin-C and human tendon degeneration. Am. J. Pathol. 149: 933-943.

SCHEDIN P, STRANGE R, MITRENGA T, WOLFE P, KAECK M (2000) Fibronectin fragments induce MMP activity in mouse mammary epithelial cells: evidence for a role in mammary tissue remodeling. $J$ Cell Sci 113 (Pt 5): 795-806.

SCHEDIN P, MITRENGA T, MCDANIEL S, KAECK M (2004a) Mammary ECM composition and function are altered by reproductive state. Molec. Carcinogenesis 41: 207-220.

SCHEDIN P, ECKEL-MAHAN KL, MCDANIEL SM, PRESCOTT JD, BRODSKY KS, TENTLER JJ, GUTIERREZ-HARTMANN A (2004b) ESX induces transformation and functional epithelial to mesenchymal transition in MCF-12Amammary epithelial cells. Oncogene 23: 1766-1779.

SCHEDIN P (2006) Pregnancy-associated breast cancer and metastasis. Nature Rev. 6: 281-291.

SCHEDIN P, KEELY PJ (2011) Mammary gland ECM remodeling, stiffness, and mechanosignaling in normal development and tumor progression. Cold Spring Harb Perspect Biol 3: a003228.

SHAW KR, WROBEL CN, BRUGGE JS (2004) Use of three-dimensional basement membrane cultures to model oncogene-induced changes in mammary epithelial morphogenesis. J. Mammary Gland Biol. Neoplasia 9: 297-310.

SMITH GH, SHARP R, KORDON EC, JHAPPAN C, MERLINO G (1995) Transforming growth factor-alpha promotes mammary tumorigenesis through selective survival and growth of secretory epithelial cells. Am. J. Pathol. 147: 1081-1096.

STENSHEIM H, MOLLER B, VAN DIJK T, FOSSA SD (2009) Cause-specific survival for women diagnosed with cancer during pregnancy or lactation: a registry-based cohort study. J Clin Oncol 27: 45-51.

TARASEVICIUTEA, VINCENTBT, SCHEDINP, JONES PL(2010) Quantitative analysis of three-dimensional human mammary epithelial tissue architecture reveals a role for tenascin-C in regulating c-met function. Am. J. Pathol. 176: 827-838.

THUN MJ, NAMBOODIRI MM, HEATH CW, JR. (1991) Aspirin use and reduced risk of fatal colon cancer. New Engl. J. Med. 325: 1593-1596.

TREMBLE P, CHIQUET-EHRISMANN R, WERB Z (1994) The extracellular matrix ligands fibronectin and tenascin collaborate in regulating collagenase gene expression in fibroblasts. Molec. Biol. Cell 5: 439-453.

VOLLMER G (1994) Expression of tenascin during carcinogenesis and involution of hormone-dependent tissues. Biochem. Cell Biol. 72: 505-514.

WEAVER VM, PETERSEN OW, WANG F, LARABELL CA, BRIAND P, DAMSKY C, BISSELL MJ (1997) Reversion of the malignant phenotype of human breast cells in three-dimensional culture and in vivo by integrin blocking antibodies. $J$. Cell Biol. 137: 231-245.

WILGUS TA, BERGDALL VK, TOBER KL, HILL KJ, MITRA S, FLAVAHAN NA, OBERYSZYN TM (2004) The impact of cyclooxygenase-2 mediated inflammation on scarless fetal wound healing. Am. J. Pathology 165: 753-761.

YUAN Y, NYMOEN DA, STAVNES HT, ROSNESAK, BJORANG O, WU C, NESLAND JM, DAVIDSON B (2009) Tenascin-X is a novel diagnostic marker of malignant mesothelioma. Am J Surg Pathol 33: 1673-1682.

ZENG Z, HINCAPIE M, PITTERI SJ, HANASH S, SCHALKWIJK J, HOGAN JM, WANG H, HANCOCK WS (2011) A Proteomics Platform Combining Depletion, Multi-lectin Affinity Chromatography (M-LAC), and Isoelectric Focusing to Study the Breast Cancer Proteome. Anal Chem 83: 4845-4854. 


\section{Further Related Reading, published previously in the Int. J. Dev. Biol.}

Fibronectin and tenascin-C: accomplices in vascular morphogenesis during development and tumor growth Ellen Van Obberghen-Schilling, Richard P. Tucker, Falk Saupe, Isabelle Gasser, Botond Cseh, Gertraud Orend Int. J. Dev. Biol. (2011). 55: 511 - 525 (doi: 10.1387/ijdb.103243eo)

Modeling and quantification of cancer cell invasion through collagen type I matrices

Olivier De Wever, An Hendrix, Astrid De Boeck, Wendy Westbroek,Geert Braems, Shahin Emami, Michèle Sabbah, Christian Gespach and Marc Bracke

Int. J. Dev. Biol. (2010) 54: 887-896

Role of TGF beta and myofibroblasts in supporting the propagation of human embryonic stem cells in vitro Neeraj Kumar, Prasad Pethe and Deepa Bhartiya

Int. J. Dev. Biol. (2010) 54: 1329-1336

Reprogramming of melanoma cells by embryonic microenvironments

Alejandro Díez-Torre, Ricardo Andrade, Cristina Eguizábal, Elixabete López, Jon Arluzea, Margarita Silió and Juan Aréchaga Int. J. Dev. Biol. (2009) 53: 1563-1568

Analysis of tenascin mRNA expression in the murine mammary gland from embryogenesis to carcinogenesis: an in situ hybridization study.

I Kalembey, T Yoshida, K Iriyama and T Sakakura

Int. J. Dev. Biol. (1997) 41: 569-573

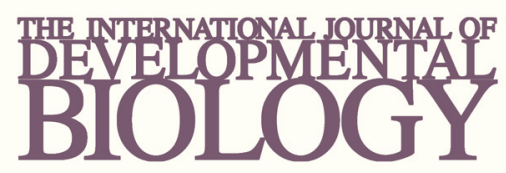

Volume 54 Nos. 6/7
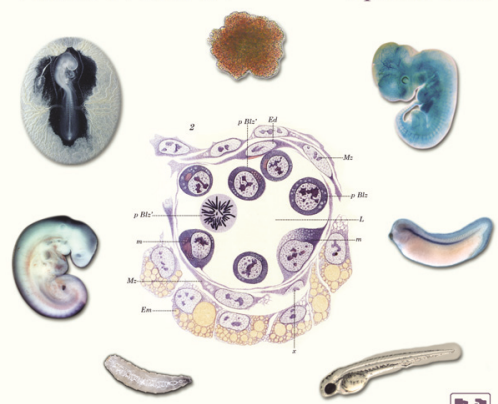

Developmental Hematopoiesis
Special Issue

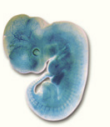

incm
5 yr ISI Impact Factor $(2010)=2.961$

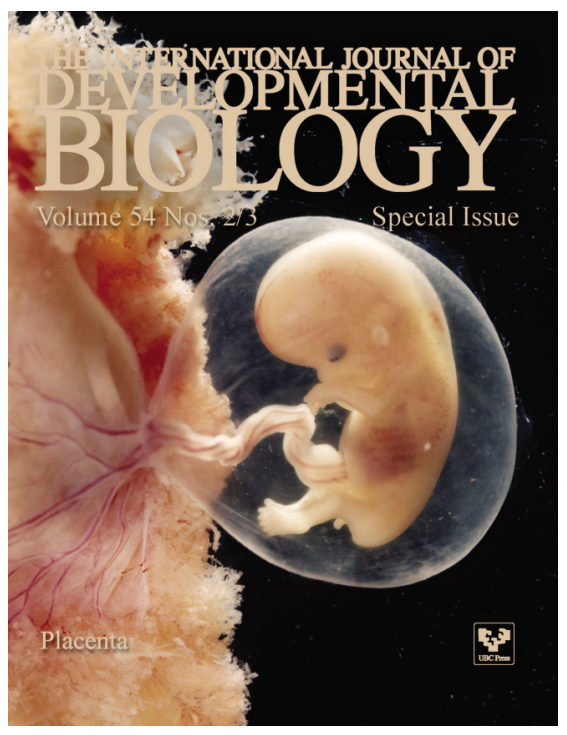

He

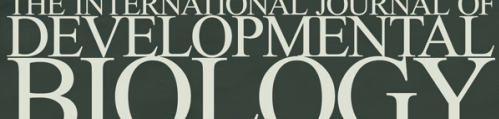
BIOLOC

Volume 55 Nos. $4 / 5$

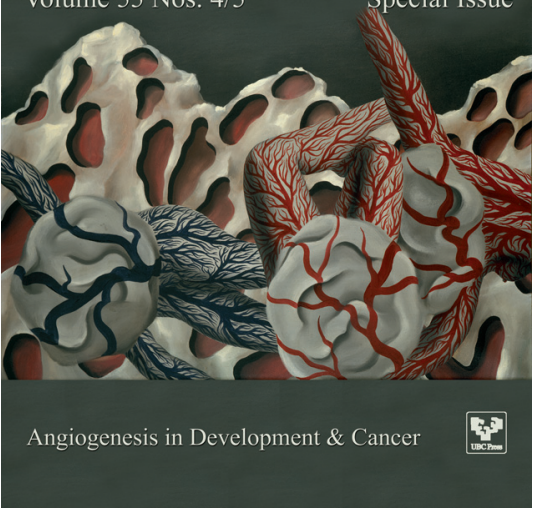

